\title{
Alberto Brambilla, Le poète et le soldat: Paul Déroulède vu par Edmondo de Amicis
}

\section{Maria Emanuela Raffi}

\section{(2) OpenEdition}

1 Journals

\section{Edizione digitale}

URL: http://journals.openedition.org/studifrancesi/2247

DOI: $10.4000 /$ studifrancesi.2247

ISSN: 2421-5856

\section{Editore}

Rosenberg \& Sellier

\section{Edizione cartacea}

Data di pubblicazione: 1 aprile 2014

Paginazione: 176

ISSN: 0039-2944

\section{Notizia bibliografica digitale}

Maria Emanuela Raffi, « Alberto Brambilla, Le poète et le soldat: Paul Déroulède vu par Edmondo de Amicis », Studi Francesi [Online], 172 (LVIII | I) | 2014, online dal 01 avril 2014, consultato il 18 septembre 2020. URL : http://journals.openedition.org/studifrancesi/2247 ; DOI : https://doi.org/ 10.4000/studifrancesi.2247

Questo documento è stato generato automaticamente il 18 settembre 2020.

\section{(c)}

Studi Francesi è distribuita con Licenza Creative Commons Attribuzione - Non commerciale - Non opere derivate 4.0 Internazionale. 


\section{Alberto Brambilla, Le poète et le soldat: Paul Déroulède vu par Edmondo de Amicis}

Maria Emanuela Raffi 


\section{NOTIZIA}

ALBERTO BRAMBILLA, Le poète et le soldat: Paul Déroulède vu par Edmondo de Amicis, in «La

Parola del testo", XVI, n. 1/2, 2012, pp. 175-195.

Pubblicato prima in due parti nella «Gazzetta letteraria», poi raccolto nei Ritratti letterari, il testo dedicato da De Amicis a Déroulède (Paolo Déroulède), costituisce un contributo piuttosto ampio nell'insieme dei Ritratti letterari pubblicati da De Amicis nel 1881, in cui compaiono altri celebri scrittori francesi fra cui Zola e Dumas. La maggiore attenzione dedicata a Déroulède viene dall'amicizia che lega i due autori, incontratisi a Parigi nel 1880, e rimasti legati da una lunga corrispondenza ma soprattutto da una straordinaria affinità di interessi essendo, come scrive Brambilla, «tous deux des hommes d'armes» e tutti due impegnati in un'operazione "de restauration d'une image positive de l'armée». È quindi in nome della "poésie patriotique européenne» che De Amicis presenta Déroulède come una figura eroica, in base al racconto fatto dallo stesso poeta francese della sua romanzesca partecipazione alla guerra franco-prussiana, per presentare e commentare poi le due raccolte poetiche Chants du soldat e Nouveaux chants $d u$ soldat, per le quali propone un titolo d'insieme: La Francia vinta. "Une subtile distinction entre l'homme et le soldat Déroulède» mostra secondo l'A. il tentativo di attenuare $\mathrm{i}$ toni revanscisti delle due raccolte poetiche da parte di De Amicis, che chiude il suo omaggio con un dettagliato ritratto fisico, nel quale Brambilla vede anche la volontà dello scrittore italiano di testimoniare la sua effettiva frequentazione del tanto ammirato amico francese. 